\title{
UBER: A Great Disrupter or Not?
}

\author{
David Lynn Hoffman \\ Metropolitan State University of Denver \\ Nina Radojevich-Kelley \\ Shenandoah University \\ Debora J. Gilliard \\ Metropolitan State University of Denver
}

In 2009, Travis Kalanick and Garret Camp created a ride sharing platform connecting drivers with passengers wanting rides in major cities throughout America. They started Uber (originally UberCab) in San Francisco, then expanded across the USA, into Europe, India, and other countries. After several missteps Travis was forced to resign. Is it possible for Uber to survive a negative reputation, negative public relation issues, attacks by the taxi and regulatory entities, and rebuild a damaged corporate culture especially during and after a pandemic?

Keywords: Uber, disruptive innovation, sustaining innovations, independent contractors, regulation of online platforms, public relations, founder issues, founders' skill sets

\section{INTRODUCTION}

\section{Prologue-the Question}

Sam is driving home from work wondering where to find a second job when he sees Sally's* Uber car pull-up next to him. Gazing at the Uber symbol on the car next to him, Sam wonders what it is like to drive for Uber- is it worth driving for them and should he consider a future job with the ride-hailing company? Sam speculates if Uber price discriminates, and wonders if they cannibalize themselves with too many drivers, would he make enough money for his time and effort, would his cousin who is a taxi driver object? Sam ponders these thoughts and can't help but wonder if Uber can overcome their reputation issues constantly in the news. Sally, the Uber passenger, stares out of the vehicle. She has connections with some of the early-stage Uber financing groups and wonders if Uber can fix its issues- can this previously great investment turn around? Sally watches as her Uber driver speeds ahead of traffic, changing lanes in front of Sam and exits the highway. Sally looks at her app, noticing her Uber driver is off route, and driving down a dark road. As the car circles back towards the route outlined on the Uber app, Sally keeps her finger poised just above the panic button? She can't help but wonder if the company will be able to overcome the constant negative media attention, and continue to attract new customers in the future? 


\section{The Disruption}

Uber emerged from a simple idea- click on a smartphone application button, hail a local driver located within minutes and get a ride to where you want to go. No cash is exchanged between passenger or driver and tips are included in the fare which is charged to member credit cards registered and stored in the Uber App (Abrosimova, 2017). Uber provides a service that allows customers to find rides quickly in cities that notoriously are overcrowded with limited taxi service availability, limited taxicab medallion opportunities for taxi expansion, strict regulations with for-hire vehicles/limousines and congested mass transit. Uber created intense rivalry with their use of new technology and innovation which disrupted the stifling taxi industry that notoriously lacked innovation since its inception in the early 1900's (Posen, 2015). As Uber grew in popularity, it sparked hatred among taxi drivers and for-hire drivers whose income and profession were now in jeopardy-many of them wanting Uber 'dead'. With this hatred competition ignited, as the transportation industry and market grappled with changes across the sector. In turn, Uber digested the notion that they were 'onto something big because everyone wanted them dead'.

Uber's business model is simple, drivers receive $80 \%$ of the fare paid by customers, while Uber keeps $20 \%$ to manage the GPS-mapping technology system, to maintain the complicated data analytics system, and payment/referral dispatch systems (Caro, 2012). More specifically, the technology Uber utilized to disrupt the transportation industry is a combination of the following: CoreLocation Framework allowing Uber to define geographic parameters and monitor device movements, MapKit to provide point to point directions, integrated mapping software which solves logistic issues, a payment integration system, push notification and SMS, a significant data analytics system and a telecommunications management system (such as with Twilio) (Abrosimova, 2017). This led Uber to become the largest global ride-share network in the world, connecting more than 5 billion trips for customers to date (Uber.com) to more than 160,000 active drivers (Dogtiev, 2018).

\section{COMPANY HISTORY \& GROWTH}

During a conference in early 2009, the idea for Uber was born when Travis Kalanick and Garrett Camp failed to find a cab in Paris, France one cold, winter night (Blythstone, 2018). Shortly after, UberCab began in San Francisco, CA as a time-share limousine application which eventually transformed into a worldwide ride-share phenomenon (Hartmans and McAlone, 2016; Saylor, 2017). Expansion went quickly for the startup across every major city in the USA, through a handful of countries across the world, with opposition and litigation in almost every city/country, and with a bountiful of investors trying to get "IN" with every venture capital funding round (Blythstone, 2018). Currently, Uber is located in 69 countries across 10,000 cities and had gross revenue of $\$ 65$ billion with 7 billion trips travelled to date (Uber, 2019 10-K).

Uber's mission is "To connect people who need a reliable ride with people looking to earn money driving their car" (Uber.com, 2018). The Company's initial tagline was "Where to?"

\section{COMPANY OPERATIONS}

\section{Services}

According to Uber's website (Uber.com), the following services are offered 1) UberRide connects drivers with passengers allowing them to get where they want to go via rideshare and an app with Uber $\mathrm{X}$ and Uber XL, 2) UberEats connects customer with food quickly by providing delivery of food from favorite restaurants, 3) UberFreight matches carriers with shippers, 4) UberBusiness provides automation of business traveler transportation needs, 5) UberATG hopes to provide autonomous car transport in the future, 6) UberHealth is a flexible scheduling service to provide rides for patients, caregivers, and staff needing healthcare rides, 7) UberBike is an electric assist bike rental system allowing people to bike around major cities, 8) UberRush which is a same-day courier service, 9) UberPool which allows drivers to pick up multiple riders during a single ride which makes it cheaper compared to Uber X or UberXL and 10) UberFresh which is lunch time food delivery transportation services. 


\section{Financials: 2019 and 2020}

In its 2019 annual report, Uber states it offered services in 69 countries and over 10,000 cities. Drivers logged over 7 billion trips and the company had 111 million monthly active platform consumers (MAPC). At fiscal year-end December 31,2019, the company reported \$14,147 million in Revenue and a net loss of $\$ 8,433$ million (FYE 2019 10-K).

The year 2020 saw changes to the environment, including a Covid 19 pandemic and new legal rulings affecting the company resulting in a negative impact for Uber's finances. The effects are noted in the September 30, 2020 year-to-date financial results. Changes and highlights for the year include:

- Institution of a no-mask, no-ride policy. Both drivers and riders are required to wear masks.

- Expansion of the Uber Green option allowing customers to book electric or hybrid vehicles. This option is now available in over 50 cities around the world.

- Partnering with GM in the US/Canada and with Renault-Nissan in Europe to pass on savings to drivers transitioning to electric vehicles.

- Gross bookings increased in 2020.

- Growth in Uber Eats with increased partnerships with restaurants throughout 2020.

- Expansion into grocery and prescription drug deliveries.

- Reached 1 million paid subscribers in the $3^{\text {rd }}$ quarter 2020.

- Passage of Proposition 22 in California allowing gig economy companied such as Uber to treat employees/drivers as independent contractors (Conger, 2020).

As of Q3 earnings reported for 2020, the company disclosed Revenues at \$8,913 million and a net loss from operations of $\$ 3,986$ million (press release, November 5, 2020).

\section{Market and Customers}

Uber customers tend to be individuals who do not own a car, do not want to drive themselves to a function, want to travel in style, or want a cost-efficient cab at their doorstep (Jungleworks, 2017). In the United States, eight percent of adults who are online use Uber at least once per month (McGrath, 2017). Individuals aged 16-34 are the most common users of Uber and make up about $66 \%$ of the company's user base (McGrath, 2017). Only six percent of its customers live outside of an urban or suburban area and about $25 \%$ come from the top income quartile (McGrath, 2017). In addition to the traditional Uber service, the company now offers Uber for Kids which works great for parents who want their children to travel to and from school via Uber and Uber for Senior Citizens which is a special service targeting seniors. Senior Citizens comprise $30-40 \%$ of all riders in many cities (Jungleworks, 2017).

\section{Uber Employees}

Uber has 16,000 employees as of January 2017, in over 60 countries and 600 cities worldwide (Uber.com, 2018). Uber drivers are not considered Uber employees, but are in fact considered selfemployed, much like an independent contractor (Uber.com, 2018). According to Uber, it does not control or direct drivers, and the most attractive feature for Uber drivers is flexibility to turn off at any time.

"Drivers are free to work or not to work, whenever and wherever they want, for as many or as little days or hours, and take any number of breaks. Drivers are their own bosses. They are paid not by Uber but by customers-Uber's sole role is to collect and distribute these payments (minus its own cut). They are free to work elsewhere, and many indeed double up for Lyft or keep their day jobs. Whereas employers typically provide workers with tools, Uber drivers use their own cars and pay for gas" (Ben-Shahar, 2017).

\section{Determination of Fares}

Uber uses price discrimination where consumers are charged different fares depending on several variables. It is a common practice used in a variety of markets such as: supermarkets, web retailers, financial services, telecommunications, electricity, gas, and insurance companies (Colombo, 2018). Airlines are 
frequent users with a variant called directional price discrimination based on the trip's origin or destination, the time of the service (business travelers will make reservations later and accept higher prices), and passengers sensitivity to price changes. Research shows that business travelers and higher income individuals are less price sensitive and accept higher prices (Luttman, 2018; Esobari, Rupp, and Meskey, 2018). Therefore, there is significant price variation depending on the time of day (Escobari, Rupp, and Meskey, 2018). Hahn et al (2018) found the practice in pop concerts, expensive entertainment venues such as classical concerts, some cable TV providers, hotel, motels, buses, and trains. Examples of variables in other markets include: the time of the service (Luttman, 2018), the seller's inventory (Colombo, 2018), the durability of the item (Hahn, Kim, Kim, and Lee, 2018), the demand for the item (Luttman, 2018), and times of the day (Colombo, 2018).

This practice allows the supplier to charge more or less depending on what it considers its relevant variables (some are mentioned above). Suppliers can use complex algorithms to determine the interplay of these variables to maximize both customer service and supplier profitability. Numerous models can be combined including scheduling models, queuing line models, and other predictive algorithms (He and Zeng, 2019).

The practice should not be confused with price manipulation where entities or individuals collude to drive up the price of an item seeking to sell theirs at higher prices. This occurred with Bitcoin and other cryptocurrencies (Rich, 2018).

\section{INDUSTRY INFORMATION (Cook, 2020)}

Although not directly and clearly part of the Taxi and Limousine Services Industry, Uber is included as a member of this industry. Uber is considered a transport network company that connect passengers and drivers through mobile applications. Ground transportation services may be considered as members of a common industry and include not only taxi services, but car rentals and ride-sharing. In the first quarter of 2018 , an analysis by SpendSmart indicates that ride-sharing comprises $70 \%$ of all ground transportation with car rentals garnering $23.5 \%$ of the market and taxis receiving $6 \%$ of ground transportation receipts (Goldstein, 2018).

The use of taxis and rental cars are losing ground while Lyft and Uber are gaining market share in the business traveler ground transportation market. Lyft continues to grow and is considered to have about $19 \%$ market share while Uber maintains its market leadership with $81 \%$ market share (Goldstein, 2018).

The taxi \& limousine services industry reported revenue of $\$ 25.2$ billion in 2020 (Cook, 2020). Cook (2020) expects a 35\% decline in 2020. Although urban areas saw more use, the increased use of ride sharing platforms impacted the industry. Up until the year 2019, the rise in consumer spending increased discretionary spending available for private transportation as opposed to public transportation. More domestic trips by US residents, along with an increase in corporate profits, influenced the use of these transportation services.

Technology substantially impacted the industry. Smartphones and mobile apps make it easier for customers to "e-hail" a ride and to make payments. Internet booking sites are available and cloud-based reservation systems (such as FastTrack) enables companies to better manage operations. Declines in oil prices and fuel expenses allow taxi/ride-hailing drivers to make greater profits. For taxi drivers, the availability of a taxi license or medallion will affect the number of drivers and competitors. Medallions (the license needed to drive a taxi) cost thousands of dollars in many cities and over \$1.3 million in New York City. The taxi industry is highly regulated, mostly by city government entities. Regulations impact the number of taxis/drivers allowed in any given city along with safety and pricing rules.

\section{UBER'S INNOVATION}

From the onset, Uber was highly innovative in the transportation industry which lacked innovation and integration of new technologies since the $20^{\text {th }}$ century (Posen, 2015). Uber was one of the first to create an easy method for connecting individuals with a transportation asset to customers looking for a fast ride. Uber 
accomplished this through the utilization of the mobile phone, allowing them to get real-time location information from the transporter to the customer. As a result, and over a very short period, Uber actively displaced an old and tired transportation service, specifically reliant on taxis and limousines, with everyday drivers looking for extra work or looking to become self-employed. Uber also integrated cutting edge data analytics and geolocation systems to keep the company moving forward.

In addition to the above, Uber continued to innovate by adding various transportation services all with a touch of a button, such as UberEat, UberRush, UberFresh, UberElevate. These new additions in the rideshare space-initiated innovations in other areas as well, such as freight. Uber rapidly expanded into UberFreight connecting carriers with shippers, eventually hoping to utilize autonomous freight technology delivered at the touch of a button. Uber moved into self-driving technology by acquiring Ottomoto for $\$ 680$ million in 2016 (Bhuiyan, 2016). The hope was to integrate this technology not only in the freight sector, but also in the passenger transportation sector over time. Unfortunately, the acquisition turned sour when Waymo sued Uber for theft and trade secret infringement resulting in a settlement payment for \$245 million of Uber stock (Jeong, 2018).

Uber recognizes the need for self-driving vehicle technology in the future and its potential not only with freight, but with passenger transportation long-term. This strategic focus and acquisition of external start-ups for technology innovations, such as Otto, are a substantial emphasis for the company's future. This corporate entrepreneurship focus resulted in Uber Freight utilizing and testing a fleet of self-driving semis that have driven across Colorado delivering beer successfully. Some may ask, why would Uber innovate towards freight? Trucking is at the heart of the USA economy generating approximately $\$ 800$ billion yearly and lacks enough truckers to deliver shipments, thus autonomous driving makes sense if the technology can get there. If Uber can tap into this industry, it is another potential for revenue.

\section{TROUBLED TIMES MANAGEMENT ISSUES}

The problem is that innovation is not enough for a company to succeed long-term. Since its inception, Uber has not been without criticism, mismanagement or disparagement. For example, after being invited to sit on President Donald Trump's Strategic Economic Advisory Council, Travis Kalanick quickly resigned due to backlash and the public's boycott. Travis stated that his resignation was due to the misinterpretation of the public viewing his participation in the President's economic/policy forum as an endorsement of Trump's beliefs, executive orders and immigration policy (Wong, 2017). Travis concluded that being a member of the council was more trouble than what it was worth and harmed his business substantially due to users deleting and boycotting the Uber App. In addition and in the wake of this turmoil, rival competitor Lyft seized the day to gain market share by donating $\$ 1$ million to the American Civil Liberties Union earning them goodwill among boycotters of Trump immigration policy amidst Uber backlash (Grabar, 2017). Lyft capitalized on the public outcry quickly and for the first time in history gained a competitive advantage that left Uber trailing for a short time.

Uber continued to have difficult years, with scandal and mismanagement continuing to plague Uber caused by media leaks of executive tier problems, sexual harassment claims (20 people fired, new board members) (Bariso, 2017, Kosoff, 2017), discrimination claims and inappropriate behavior (Bariso, 2017), executive resignations (Kosoff, 2017), bullying tactics on the job, chronic intellectual property lawsuit headlines of Waymo vs Uber, a looming federal probe on data breaches in 2016 (Greyball...using data to deceive) and continual criticism of Uber's brash, take-no prisoner, leadership style which was widely publicized and unpopular.

As if the above was not bad enough, Uber became riddled with a substantial CEO problem and increased litigation issues. Travis was criticized for screaming at an Uber driver, losing control often with employees and the press, mishandling the press repeatedly, utilizing an authoritative leadership style, and having a Trump connection. Eventually, investors and a handful of major shareholders demanded Travis Kalanick's resignation, calling for a change in leadership, which resulted in the hiring of new CEO, Dara Khosrowshahi. Uber was catapulted into a tailspin of damage control, strategic renewal and emotional intelligence recovery. 


\section{STRATEGIC RENEWAL \& BRAND REPAIR/ EMOTIONAL INTELLIGENCE \& NOW WHAT?}

Towards the end of 2017, Dara Khosrowshahi stepped in as CEO of Uber and immediately received unfortunate news that London, UK would not renew the Uber license allowing them to continue operations as before (Bariso, 2017). Dara realized he inherited a company with a bad reputation, riddled with issues, and a terrible corporate culture. Dara responded in a surprising manner by sending emails and apologies to the community and to employees, proving to be the much-needed change in leadership. The following is an excerpt from an email Dara sent to employees "while the impulse may be to say that this is unfair, one of the lessons I've learned over time is that change comes from self-reflection. So, it's worth examining how we got here. The truth is that there is a high cost to a bad reputation. Irrespective of whether we did everything that is being said about us in London today (and to be clear, I don't think we did), it really matters what people think of us, especially in a global business like ours, where actions in one part of the world can have serious consequences in another" (Bariso, 2017). With rhetoric like this and strong action, Dara set Uber on an emotional intelligence pathway of understanding how emotions guide behavior, of looking at the bigger picture and learning from other perspectives. There is a general consensus coming from the CEO suite that any negative feedback Uber receives can lead to needed improvements and there is a deep understanding that what worked in the past, cannot work in the future for Uber. According to Kolhatkar (2018), Dara Khosrowshahi understands that he is charged with fixing the eight-year-old start-up riddled with scandal in the hope of moving it onward to bigger and better things.

\section{UBER'S IPO (INITIAL PUBLIC OFFERING)}

The mood at the stock exchange for Uber's initial public offering started out high and quickly soured as the groups bringing the IPO dropped their initial expectation to begin at $\$ 50$ per share. Upon realizing that they did not have enough demand, the offering price dropped to $\$ 45$, and continued to drop during the first two trading days to $\$ 41.95$ by Friday of the first week. (Driebusch, Farrell, and Chung, 2019).

Analysts believed that the early big investors such as BlackRock, Inc and Tiger Global Management dampened the demand by selling portions of their early investments. Tiger Global had offered to sell large portions in the week leading up to the IPO. This shaky IPO mirrored Lyft's IPO, which also performed much less than expected. Both Lyft and Uber joined the rare IPO's that fall in the first days of trading while other IPOs are successful (Driebusch, Farrell, and Chung, 2019). Speculation as to what caused these IPO's to underperform is still being debated by valuation experts.

\section{A SUMMARY OF UBER'S KEY EVENTS}

- In 2009 the idea is born when Travis Kalanick and Garrett Camp cannot get a cab in Paris in cold weather.

- Subsequently, Travis and Garrett launched UberCab in San Francisco, CA (Stone, 2017). They pursue a vision of using an internet platform to connect drivers willing to transport riders to wherever they want to go.

- The founders successfully engaged venture capitalists to start the business.

- Uber opened in Puerto Rico without government approval and were hit with sanctions (Costa, 2016).

- They obtained permission from several states and cities to enable ride sharing permission (Posen, 2015).

- Won a federal appeals court ruling which moved a dispute with two Uber drivers to arbitration.

- President Trump invites Kalanick to join his advisor council. Kalanick joins, but eventually resigned (Newcomer and Stone, 2018).

- The EU launches inquiries and court injunctions (DeMasi, 2016). 
- Uber got crossways with Apple for tracking the location of riders. Uber claimed that it was trying to thwart thieves from China who would create an Uber account, request rides, and then wipe out the account and start over (McGarry, 2017).

- Instead of working carefully with Google, Uber alienated them by starting development of self driving trucks. A Google lawsuit alleges that former Google employees working with an Uber related firm brought five disks of Google data containing designs, files, engineering documents, and software from Google's venture (Newcomer and Stone, 2018).

- Was charged by the Federal Trade Commission in August 2017 with failing to adequately protect driver and user information.

- Was rocked by several complaints of a culture allowing sexual harassment and discrimination (Griffen et at 2018).

- A video surfaced of Kalanick yelling obscenities at an Uber drive, Fawzi Kamel. The board sees the video. Video gets put online somehow (Newcomer and Stone, 2018).

- Allegedly developed a secret technology called Greyball which allowed Uber to identify and deny service to riders who violated their contracts. Allegedly same technology (Greyball) was used to avoid taxi inspectors and other law enforcement officials (Newcomer and Stone, 2018).

- Kalanick argues that the company's problems were not his fault or a cultural problem. In his view, the problem was a public relations issue (Newcomer and Stone, 2018).

- By January 2017, Uber was in 60 countries and 600 cities worldwide (Uber.com, 2018).

- In 2017 and 2018 after years of negative reports, spying on passengers, the lawsuit with Google, and Kalanick boasts of his female conquests, the new hashtag, \#deleteuber, comes out. Many customers drop Uber giving Uber's competitor- Lyft, an entry into the market (Newcomer and Stone, 2018).

- Kalanick continued to be defensive and combative. Eventually he alienated investors, employees and his board. According to Newcomer and Stone (2018), he turned former friends into enemies.

- Kalanick ranked last among tech CEOs (Newcomer and Stone, 2018).

- Kalanick met Kamel for over an hour and then offered him Uber stock - a suspected financial transaction according to the article by Newcomer and Stone (2018). The meeting ended positively.

- After Uber lawyers determined that the company should not pay Kamel in stock, Kalanick pays him \$200,000 from his own funds (Newcomer and Stone, 2018).

- A technology magazine published an alleged visit by Kalanick and other Uber executives to a karaoke bar in Seoul in 2014 where the bar was staffed by female "escorts" who were "labeled" easy identification by customers. His then girlfriend stated that Kalanick left with her after an hour (Newcomer and Stone, 2018).

- In June Bloomberg News reported that Eric Alexander, Uber's president for Asia-Pacific obtained the confidential medical records from a rape victim, 26-year-old passenger, by an Uber driver in Delhi (Newcomer and Stone, 2018). Many employees are discouraged and stay home (Newcomer and Stone, 2018).

- Six members of Uber's Executive Leadership team send a confidential letter to the board suggesting that Emil Michael, Alexander's boss and Kalanick's closest deputy be fired, and that Kalanick take three months of leave (Newcomer and Stone, 2018).

- Into 2017 Kalanick became less communicative and missed meetings. The venture capital firm Benchmark becomes concerned.

- Travis would come into the office and give instructions without consulting with the then CEO.

- The board met and reviewed a report by the Holder law firm, Covington \& Burling who issued 47 recommendations

- Arianna Huffington, the media entrepreneur, and Kalanick's ally on the board, held an all hands board meeting which recommended Kalanick take a leave of absence (Newcomer and Stone, 2018). 
- However, Travis kept dialing into conference calls, reviewed internal data, and recruited candidates for the open board seats (Newcomer and Stone, 2018).

- Benchmark decides that Kalanick must leave and reaches out to other investors. They all sign a letter requesting Travis to resign (Newcomer and Stone, 2018).

- The pressure mounts as this group met Kalanick and told him to resign or they would go public with their allegations (Newcomer and Stone, 2018). Kalanick signs the documents of resignation. (Newcomer and Stone, 2018).

- Unfortunately, the New York Times ran a complete story of the resignation.

- Kalanick continues to recruit board members according to Newcomer and Stone (2018) who hint that he may have had plans for a comeback like Steve Jobs did with Apple.

- Benchmark sues Kalanick for fraud and fiduciary breach (Newcomer and Stone, 2018).

- Uber hires a new CEO, Khosrowshahi, who was reported to be a good listener and a diplomat who visited with taxi regulators and wrote an open letter apologizing for Uber's past actions (Newcomer and Stone, 2018).

- Softbank and investors work a complete buy out in the billions for Kalanick (Newcomer and Stone, 2018).

- Uber obtains a new COO (Chief Operating Officer) Barney Hareford.

- By 2018 Uber had 160,000 active drives with $\$ 20$ billion in gross revenue and have received $\$ 12$ billion in venture capital funding (Blystone, 2018).

- Uber's initial public offering (IPO) started lower than expected at $\$ 45$ per share then dropped to $\$ 41.95$. Analysts suggest that early investors sold their stock at the IPO lowering demand and the price (Driebusch, Farrell, and Chung, 2019 May 20).

- California passed AB5 which attempted to address "gig economy" workers. Although Uber made some changes by increasing driver compensation, California regulators sued Uber.

- Uber, Lyft, DoorDash and other gig economy players poured over \$203 million into convincing California voters to approve Proposition 22 which exempted them from classifying drivers as employees.

- In February 2021, the United Kingdom's Supreme Court ruled that a group of former Uber drivers should have received minimum wages and other benefits. The court's unanimous decision upheld lower court decisions. The decision only affects the 25 former drivers it may set a precedent for Uber's current drivers and other gig workers. (Schechner, 2021).

\section{UBER 2020, 2021 AND BEYOND}

Initially the new CEO received a positive reception from investors when he first arrived in May 2019 (Lashinksy, 2020). But the 2019 losses concerned his investors and he lost several managers including his Chief Operations Officer who he had brought from Expedia. He was criticized for focusing on numbers, instead of operations or innovation (Lashinksy, 2020).

\section{COVID 19 PANDEMIC}

To his credit, Khosrowshahi saw what the virus did to Uber's business in Taiwan and Hong Kong and immediately set up a task force (Lashinksy, 2020). Uber quickly went into action and changed its application to ensure that riders understood the local restrictions. In addition, they hired a prestigious agency Wieden+Kennedy to create a tag line - "thank you for not riding," and changed its management team and Board of Directors. Although, it lost $80 \%$ of its volume, Dara Khosrowshahi was optimistic in 2020 that they would survive. 


\section{REGULATIONS}

California passed AB5 which went into effect January 1, 2020 containing a three-part test to determine if workers were employees or independent contractors (Rana, 2020). Uber tried to comply by improving wages and providing some sick pay. Uber argued that the law was unconstitutional and if it was constitutional it did not apply to them. Uber's argument was that it was an application company that connected passengers and drivers. Each driver used their own car and paid for gas, tolls, and expenses. Uber argued that it ratified changes allowing drivers flexibility to set their prices, set their hours and enable riders to request trips with specific drivers (Siddiqui, 2020). This argument does have support from a study of Uber drivers which found that working for Uber doubled their income compared with less flexible work arrangements (Chen, Chevalier, Rossi, 2019). In addition, Uber argued that AB5 would hamper their business model to the point that the business could not function (Siddiqui, 2020). Uber reasoned that AB5 compliance would lengthen wait times for drivers, fare rates would increase due to increased operational costs and various cities would become unattractive. Uber would be forced to exit markets, such as California, due to employee onboarding and driver dispatch complications and costs caused by AB5 compliance (Siddiqui, 2020). Uber claimed that their current employment model allowed drivers to be their own hiring entity, and AB5 fundamentally changed that model and freedom for Uber drivers (Siddiqui, 2020).

Uber, Postmates, Lyft and other Gig-economy companies, along with an Uber driver and Postmates courier sued the state of California claiming AB5 unfairly targets modern "app" companies, while granting dozens of exemptions to professionals who lobbied heavily the Legislature. They claim that AB5 grants several profession exemptions, while at the same time prevents drivers and couriers from "pursing their chosen occupation as business owners in the sharing economy" (Siddiqui, 2020). Uber, Lyft, DoorDash and other gig economy companies poured more than \$203 million into convincing California voters to approve Proposition 22 which exempted them from classifying drivers as employees. Feiner and Kolodny (2020) expect them to either use or threaten to use the same tactic in other states.

Spicer, Eidelman and Zwick (2019) studied Uber's tactics in 10 North American cities. In nine of the ten cities local regulators mounted stubborn resistance with a variety of tactics: cease and desist orders, legal injunctions, statewide bans, enforcement of local regulations, fines and charges. In all ten cities, Uber achieved legal status by openly negotiating with regulators or confronting them and forcing them to change. Uber's strategy depended on the kinds of regulations they faced and whether the local regulators saw Uber as being complimentary or harmful to their existing markets. Spicer et al (2019) argue that Uber's actions created not only market disruption but policy disruption.

The result of all the lobbying was the ballot initiative called Proposition 22 in California which passed by $58 \%$ granting an exception of classification to Assembly Bill 5 (AB5) allowing app-based transportation and delivery companies to classify their employees as independent contractors (Conger, 2020). This was victory for companies such as Uber, DoorDash, and Lyft who could continue to classify their workers as independent contractors in the state of California (Conger, 2020).

Uber not only faces regulatory issues in the Americas but also in the EU and UK. Dierken (2018) argues that the EU VAT tax does apply to Uber because their legislation states that services in the sharing economy are taxable transactions and subject to the VAT. Uber states -again- that it is a technology platform because it reverse charges, its drivers are independent contractors, and Uber's Dutch subsidiary controls the VAT rates, thus it is shielded from these laws (Dierken, 2018). Dierken (2018) concludes that Uber is illegally pursuing tax evasion not tax avoidance.

As noted above the United Kingdom's Supreme Court unanimously upheld lower court decisions that 25 former Uber drivers should have received minimum wages and other benefits. While the decision only affected these former drivers, labor activists believe that the decision sets a precedent for current Uber and other gig economy workers (Schechner, 2021). Uber claims that the decision does not automatically pertain to all of its UK drivers and does not affect its Uber Eats food delivery business (Schehner, 2021). 


\section{THOUGHTS AND QUESTIONS GOING FORWARD}

Will the goodwill Uber created in its response to the pandemic keep old customers and attract new ones to Uber? How should Dara and the executive team prepare for the changing environment, social trends, competitive landscape, and uncertainty about the pandemic's economic effects going into 2021 and beyond? How is Uber stock currently performing- will it keep its investors satisfied? Has the company reinvigorated the brand or is it still struggling? Will Uber continue to use the same policy disruption tactics to achieve legal status where it operates - would this work elsewhere, in the EU, and England? These questions and many more remain at the forefront of our minds.

\section{CONCLUSION}

Critics and some judges point out that current legal framework does not cover the gig workers of today who are in the "middle" between the two. They are not totally under the control of an employer. Do any of the following tests work in this new economy, is new legislation needed to cover the new reality, should the above tests be used, or should this phenomenon be left outside of any government regulation? With respect to Uber, should they consider their drivers employees or independent contractors?

\section{ACKNOWLEDGEMENT}

An earlier version of this paper was presented at the WDSI Conference 2020.

\section{REFERENCES}

Abrosimova, K. (2017). Building an app like Uber: What is the Uber app made from? Retrieved July 8, 2018, from https://yalantis.com/blog/uber-underlying-technologies-and-how-it-actually-works/

Bariso, J. (2017). Uber just fired 20 employees. Here's why, summed up in 1 powerful sentence. Retrieved May 11, 2018, from https://www.inc.com/justin-bariso/uber-just-fired-20-employeesheres-why-summed-up-in-one-powerful-sentence.html

Bariso, J. (2017). Uber's new CEO just sent an amazing email to employees - and taught a major lesson in emotional intelligence. Retrieved on May 10, 2018, from https://www.inc.com/justinbariso/ubers-new-ceo-just-sent-an-amazing-email-to-employees-taught-a-major-lesson-inemotional-intelligence.html

Ben-Shahar, O. (2017). Are Uber drivers employees? The answer will shape the sharing economy. Retrieved July 12, 2018, from https://www.forbes.com/sites/omribenshahar/2017/11/15/are-uberdrivers-employees-the-answer-will-shape-the-sharing-economy/\#1bf08a8c5e55

Berg, J., \& Johnston, H. (2019, January 1). Too Good to be true? A comment on Hall and Krueger's analysis of the labor market for Uber's driver-Partners. IIL Review, 72I(1), 36-68.

Bhuiyan, J. (2016). Uber paid $\$ 680$ million for self driving truck company Otto for the tech, not the trucks. Retrieved July 22, from https://www.recode.net/2016/8/18/12540068/uber-paid-680million-for-self-driving-truck-company-otto-for-the-tech-not-the-trucks

Bhuiyan, J. (2018, May 23). Uber turned a profit thanks to its deals in Southeast Asia and Russia. Retrieved July 2018, from https://www.recode.net/2018/5/23/17380952/uber-2018-financialsyandex-grab-softbank

Blystone, D. (2018). The story of Uber. Retrieved July 10, 2018, from https://www.investopedia.com/articles/personal-finance/111015/story-uber.asp

Bower, J.L., \& Christensen, C.M. (1995, January-February). Disruptive technologies: Catching the wave. Harvard Business Review.

Chen, M.K., Chevalier, J.A., \& Rossi P.E. (2019). The value of flexible work: Evidence from Uber drives. Journal of Political Economy, 127(6), 2735-2794. 
Christensen, C.M., Raynor, M., \& McDonald, R. (2015, December). The Big Idea: What is Disruptive Innovation? Harvard Business Review, pp. 46-53.

Caro, M.D., (2012, September 25). From the Draconian to the Inane: Uber CEO rips proposed DC regulations. TransportationNation.com.

Colombo, S. (2018, February). Behavior and characteristic based price discrimination. Journal of Economics and Management Strategy, 27(2), 237-250.

Conger, K. (2020, November 4). Uber and Lyft drivers in California will remain contractors. The New York Times. Retrieved January 24, 2021, from https://www.nytimes.com/2020/11/04/technology/california-uber-lyft-prop-22.html

Cook, D. (2020). Taxi and Limousine Industry. IBIS.

Corsi, S., \& Di Minin, A.D. (2014). Disruptive innovation...in reverse: Adding a geographical dimension to disruptive innovation theory. Creativity and Innovation Management, 23(1), 76-90.

DOI:10.1111/caim.12043

Costa, D. (2016, July). Uber Puerto Rico Launch Hits a Pothole. Caribbean Business, 2(27), 8.

DeMasi, A. (2016, January). Uber: Europe's backseat drive for the sharing economy. Creighton International and Comparative Law Journal, 7, 73-85.

Dess, G.G., McNamara, G., Eisner, A.B., \& Lee, S. (2019). Strategic Management text and cases (9th ed.). McGraw-Hill.

Dierken, B.V. (2018, Fall). Uber's international tax scheme: Innovative tax avoidance or simple tax evasion. Syracuse Journal of International Law \& Commerce, 46(1), 223-260.

Driebusch, C., \& Roof, K. (2019, April 26). Uber lowers target price for IPO. The Wall Street Journal.

Driebush, C., Farrell, M., \& Chung, J. (2019, May 20). Early big investors in Uber undermined market debut. The Wall Street Journal, 273(117), A1.

Dogtiev, A. (2018). Uber revenue and usage statistics 2017. Retrieved July 3, from http://www.businessofapps.com/data/uber-statistics/

De Jong, M., \& van Dijk, M. (2015). Disrupting beliefs: A new approach to business-model innovation. McKinsey Quarterly $3^{\text {rd }}$ Quarter.

Dierken, B.V. (2018, September 1). UBER's international tax scheme: Innovative tax avoidance or simple tax evasion? Syracuse Journal of International Law and Commerce, 46(1), 223-260.

Escobari, D., Rupp, N.G., \& Meskey, J. (2019). An analysis of dynamic price discrimination in airlines. Southern Economic Journal, 65(3), 639-662.

Feiner, L., \& Kolodny, L.O. (2020, November 5). Uber and Lyft eye other states after California ballot victory. $C N B C$. Retrieved from https://www.cnbc.com/2020/11/05/after-their-projected-victoryin-california-labor-law-fight-gig-companies-like-uber-and-lyft-eye-other-states.html

Gobble, M.M. (2015). The case against disruptive innovation. Research Technology Management, 58(1), $59-61$.

Goldstein, M. (2018, April 30). Destruction of taxi industry by Uber, Lyft affects Trump lawyer Michael Cohen. Forbes. Retrieved July 2018, from www.forbes.com/sites

Graber, H. (2017). The Uber boycott and Lyft's ACLU donation herald a new era of corporate politics. Retrieved July 20, 2018, from http://www.slate.com/blogs/moneybox/2017/01/30/the_uber_boycott_and_lyft_s_aclu_donation_ herald_a_new_era_of_corporate.html

Griffin, D.A., Van Esch, P., \& Trittenbach, M. (2018, July). Investigating the mediating effect of Uber's sexual harassment case on the brand: Does it matter? Journal of Retailing and Consumer Services, 43, 111-118.

Hahn, J., Kim, J., Kim, S., \& Lee, J. (2018, May). Price discrimination with loss aversion consumers. Economic Theory, 5(3), 681-728.

Hall, J.V., \& Kreger, A.B. (2018). An analysis of the labor market for Uber's Driver-Partners in the United States. ILR Review, 71(3), 705-732.

Hargrove v. Sleepy's LLC 106 A.3d 449, 458. (N.J. 2015). 
He, Y., \& Zeng, S. (2019, March). Price discrimination in sharing economy. Western Decision Sciences 2019 Conference Proceedings.

Hartmans, A., \& McAlone, N. (2016). The story of how Travis Kalanick built Uber into the most feared and valuable startup in the world. Retrieved June 15, from https://bit.ly/3xNLijM

Jeong, S. (2018). Who blinked first in Waymo v Uber? Why Uber and Waymo settled its high-stakes case. Retrieved July 21, 2018, from https://www.theverge.com/2018/2/9/16997394/waymo-v-ubertrial-settlement-explained

Jungleworks. (2017, December). How Uber works: Business revenue model. Retrieved July 2018, from https://jungleworks.com/uber-business-model-revenue-insights

Kolhatkar, S. (2018). At Uber, a new CEO shifts gears. Retrieved July 19, 2018, from https://www.newyorker.com/magazine/2018/04/09/at-uber-a-new-ceo-shifts-gears

Kosoff, M. (2017). Mass firings at Uber as sexual harassment scandal grows. Retrieved June 1, 2018, from https://www.vanityfair.com/news/2017/06/uber-fires-20-employees-harassment-investigation

Lepore, J. (2014, June). The disruptive machine: What the gospel of innovation gets wrong. The New Yorker. Retrieved from http://www.newyorker.com/magazine/2014/06/23/the-disruption-machine

Luttman, A. (2018, March). Evidence of directional price discrimination in the U.S. airline industry. International Journal of Industrial Organization, 62, 291-329.

McGarry, C. (2017). How Uber ran afoul of Apple's privacy rules. Macworld - Digital Edition, 34(6), 63-64.

McGrath, F. (2017, August 16). The demographics of Uber's US users. Retrieved July 2018, from www.globalwebindesx.com/case-studies

Newcomer, E., \& Stone, B. (2018, January 22). The fall of Travis Kalanick was a lot weirder and darker than you thought. Bloomberg Businessweek, (4555).

Posen, H.A. (2015). Ridesharing in the sharing economy: Should regulators impose Uber regulations on Uber? Iowa Law Rev., 101, 405-433.

Recent adjudication: Employment Law-National Labor Relations Act-NLRB classifies canvassers as employees, not independent contractors. (2016). Harvard Law Review, 129, 3039.

Rena P. (2020, January 5). Uber changes California Fare Calculation. Wall Street Journal, Eastern Edition, New York, B5.

Rich, G. (2018, May 24). Bitcoin suffers another blow as DOJ targets price manipulators. Investor's Business Daily.

Schechenr, S. (2021, February 20). Uber loses drivers' challenge in U.K. Wall Street Journal, (41).

Schmidt, G.M., \& Druehl, C.T. (2008). When is a disruptive innovation disruptive? Product Development and Innovation Management, 25, 347-360.

Siddiqui, F. (2020, October 13). Judges raise questions about Uber and Lyft's arguments in employment cases. The Washington Post. Retrieved January 20, 2021, from https://www.washingtonpost.com/technology/2020/10/13/uber-lyft-ab5/

Sisters' Camelot (363 NLBR No. 13 Sept. 25, 2015).

Stafford, B.E. (2016, Winter). Comment: Riding the lie between 'employee' and 'independent contractor' in the modern sharing economy. Wake Forest Law Review, 51, 1223.

Stone, B. (2017, January 30). How Uber fought city halls, outlasted rivals and Airbnb won over the citizenry, figured out the sharing economy. Bloomberg Business Week.

Uber Annual Report FYE. (2019). Retrieved January 5, 2020, from https://s23.q4cdn.com/407969754/files/doc_financials/2019/ar/Uber-Technologies-Inc-2019Annual-Report.pdf

Uber. (2020, November 5). Press release. Uber Announces Results for Third Quarter 2020. Retrieved January 5, 2020, from https://investor.uber.com/news-events/news/press-releasedetails/2020/Uber-Announces-Results-for-Third-Quarter-2020/

Uber.com. (2018). website. Retrieved from www.uber.com.

Uber.com. (2021). website. Retrieved from www.uber.com 
Utterback, J.M., \& Acee, H.J. (2005). Disruptive technologies: An expanded view. International Journal of Innovation Management, 9(1), 1-17.

Utterback, J.M., \& Acee, H.J. (2015). Is disruption theory wearing new clothes or just naked? Analyzing recent critiques of disruptive innovation theory. Innovation, 17(4), 417-428. DOI: $10.1080 / 14479338.2015 .1061896$

Weeks, M.R. (2015). Is disruption theory wearing new clothes or just naked? Analyzing recent critiques of disruptive innovation theory. Innovation, 17(4) 417-428. DOI. $10.1080 / 14479338.2015 .1061896$

Wong, J.C. (2017). Uber CEO steps down from Trump advisory council after users boycott. Retrieved July 21, from https://www.theguardian.com/technology/2017/feb/02/travis-kalanick-delete-uberleaves-trump-council

\section{APPENDICES}

\section{Appendix 1: A Short Primer on Disruptive, Cost, and Sustaining Innovations and Refinements to Disruption Theory \\ History}

Bower and Christensen (1995) introduced the concept of disruptive innovation in a 1995 Harvard Business Report. Their article initiated a wide discussion in the academic literature about what is a disruptive technology with claims, blunt criticisms, and harsh counter criticisms. Christensen, Raynor and McDonald's (2015) states that disruption occurs when a successful incumbent in an industry initially ignores an entreat that starts at the lower priced end of their market. The incumbent focuses on their core business clients with incremental improvements (sustaining innovations) to their product or service to keep these core business clients satisfied. This approach ignores the overlooked or underserved customers and incumbents do not see a need to respond. As an example, Xerox focused on its high customers and ignored the cheaper models until they improved and moved up the market.

However, as an entrant slowly improves their product or service they move up the market to higher priced, more profitable clients. According to Christensen et al (2015) disruption occurs when these mainstream customers accept the entrant's offerings. They argue that disruption does not occur if the entrant targets a well-served market - disruption always starts at the low end or unserved markets. Characteristics of disruptive businesses are lower prices, lower gross margins, smaller markets, less sophisticated products and services. They may displace existing competitors and may enlarge existing markets and provide new functionalities (Corsi and DeMinin, 2014).

In addition to the above, Christensen et al's (2015) state that disruption can occur when an entrant creates a new market. Entrants may add amenities or improve quality as they become more successful. They emphasize that with both disruption scenarios, change is not a point in time, but a process (Christensen et al, 2015).

Christensen et al's (2015) examples of non-disruptive changes include: the addition of a fifth blade to razors, higher definition TVs or more advanced mobile phones. They are quick to point out that these changes are not disruptive changes but are instead examples of incremental improvements or sustaining innovations (Christensen et al, 2015).

\section{Criticisms of the Disruption Theory}

The theory has generated substantial research and criticism. The primary critic was Jill Lepore (2014) who attempted to discredit the disruption theory by questioning Christensen et al's use of cases that were chosen to justify the theory, especially with labeling the iPhone as a sustaining innovation. Other critiques argue that the key parts of the theory are vague, imprecise (Weeks, 2015; Gobble, 2015) and lack predictive power (Utterback and Acee, 2005).

A counter criticism of Lepore was delivered by Weeks (2015) who argued that her attack on the theory was unfounded and that parts of the theory have been completed. Weeks (2015) suggested that the definitions need more precision. 


\section{Refinements to the Theory}

Christensen et al responded to critiques by arguing that change is a process overtime. De Jong and van Dijk (2015) believe that business models are not as "durable" as in the past. They point out that every industry is built around a set of "beliefs" or assumptions about their business models and attempt to lock in their customers with loyalty or amenities. They believe that loyalty can be built with transparency - give customers more information and decision making. Their approach is: 1) outline the predominate business model, 2) discern the underlying belief, 3) turn the belief on its head, 4) verify that the belief is valid or reframe it and 5) translate the reworked belief into your business model.

\section{Other Refinements}

Schmidt and Druehl (2008) mapped the type of innovation to the type of disruption which explains how a sustaining innovation could start at the high end and work down.

\section{Appendix 2: Schmidt and Druehl's (2009) Mapping of the Type of Innovation to the Type of Disruption}

(Note: This is an exact replica of the authors' table for student analysis only.)

\begin{tabular}{|c|c|c|c|}
\hline Type of Innovation & Type of Diffusion & Description & Example \\
\hline Sustaining Innovation & $\begin{array}{l}\text { High-end } \\
\text { encroachment }\end{array}$ & $\begin{array}{l}\text { The new product first } \\
\text { encroaches on the high end of } \\
\text { the existing market and then } \\
\text { diffuses downward. }\end{array}$ & $\begin{array}{l}\text { Pentium IV relative } \\
\text { to Pentium III }\end{array}$ \\
\hline Disruptive Innovation & $\begin{array}{l}\text { Low-end } \\
\text { encroachment }\end{array}$ & $\begin{array}{l}\text { The new product first } \\
\text { encroaches on the low end of } \\
\text { the existing market and then } \\
\text { diffuses upward. }\end{array}$ & \\
\hline \multirow[t]{2}{*}{$\begin{array}{l}\text { New-Market } \\
\text { Disruption }\end{array}$} & $\begin{array}{l}\text { Fringe-market low-end } \\
\text { encroachment }\end{array}$ & $\begin{array}{l}\text { Before encroachment begins, } \\
\text { the new product opens up a } \\
\text { fringe market (where } \\
\text { customer needs are } \\
\text { incrementally different from } \\
\text { those of current low-end } \\
\text { customers). }\end{array}$ & $\begin{array}{l}\text { 5.25. inch drive } \\
\text { relative to } 8 \text {-inch } \\
\text { drive }\end{array}$ \\
\hline & $\begin{array}{l}\text { Detached-market low } \\
\text { end encroachment }\end{array}$ & $\begin{array}{l}\text { Before encroachment begins, } \\
\text { the new product opens up a } \\
\text { detached market (where } \\
\text { customer needs are } \\
\text { dramatically different from } \\
\text { those of current low-end } \\
\text { customers). }\end{array}$ & $\begin{array}{l}\text { Cell phone relative } \\
\text { to land line. }\end{array}$ \\
\hline Low-end disruption & $\begin{array}{l}\text { Immediate low-end } \\
\text { encroachment }\end{array}$ & $\begin{array}{l}\text { Low-end encroachment begins } \\
\text { immediately upon } \\
\text { introduction of the new } \\
\text { product }\end{array}$ & $\begin{array}{l}\text { Discount relative to } \\
\text { department stores }\end{array}$ \\
\hline
\end{tabular}

Source: Schmidt, G.M. and Druehl, C.T. (2008). When is a disruptive innovation disruptive? Product Development and Innovation Management 25 347-360. 


\section{Appendix 3: Utterback and Acee (2005) A Map of Competitive Advantage Due to Technological Change}

Utterback and Acee's (2005) typology has 24 categories depending on cost, traditional performance, and ancillary performance. Does the Uber example fit one of the following?

(Note: this is an exact replica of the authors' table for student analysis only).

\begin{tabular}{llll}
\hline \multicolumn{1}{c}{ Cost } & \multicolumn{1}{c}{$\begin{array}{c}\text { Traditional } \\
\text { Performance }\end{array}$} & Ancillary Performance & \multicolumn{1}{c}{ Examples } \\
Lower & Lower & Higher & Christensen case Hard \\
Lower & Higher & Higher & $\begin{array}{l}\text { disc drives } \\
\text { Compact disc/vinyl } \\
\text { album }\end{array}$ \\
Lower & Lower & Lower & Wafer board/plywood \\
Lower & Higher & Lower & $\begin{array}{l}\text { Oriented strand } \\
\text { board/plywood }\end{array}$ \\
Higher & Lower & Higher & $\begin{array}{l}\text { Digital/film camera } \\
\text { Higher }\end{array}$ \\
Higher & Higher & Higher & $\begin{array}{l}\text { Fuel } \\
\text { injection/carburetor } \\
\text { Wartime substitutes }\end{array}$ \\
Higher & Lower & Lower & $\begin{array}{l}\text { Electronic } \\
\text { calculator/slide rule }\end{array}$ \\
\hline
\end{tabular}

Source: Utterback, J.M. and Acee, H.J. (2015). Is disruption theory wearing new clothes or just naked? Analyzing recent critiques of disruptive innovation theory. Innovation 17 (4) 417-428. DOH: 10.1080/14479338.2015.1061896

\section{Appendix 4: Test of a Disruptive Innovation (Author and Article in the Teaching Note)}

The following is a possible test for disruptors (reference in the teaching case):

1. "Does it target non-consumers or people who are overserved by an incumbent's existing offering in the marketplace." For this question examine who the entrant serves in the marketplace. Where did they start- high or low in the marketplace? They use the term overserved - what they are asking is there a group of consumers who are not using the incumbents' service because of price, convenience or something else?

2. "Is the offering not as good as an incumbent's existing offering as judged by historical measures of performance." This question asks about performance how was the entrant's initial performance versus the traditional providers?

3. "Is the innovation simpler to use, more convenient or more affordable than the incumbent's existing offering." For this question examine the cost and convenience of the incumbent's offering.

4. "Does the offering have a technology enabler that can carry its value proposition around simplicity, convenience, affordability upmarket and allow it to improve." This asks can this platform or technology be upscaled or used to serve other markets or customers?

5. "Is the technology paired with a business model innovation that allows it to be sustainable with its new value proposition." This is a suitability question- can the incumbent survive- is it profitable or could it be? 
6. "Are existing providers motivated to ignore the new innovation and not threatened at the outset." What is the reaction of the incumbents? Do they ignore and then fight the incumbent or do they fight from the appearance of the incumbent? What is their reaction early and laterdo they see themselves as affected and to what degree?

\section{Appendix 5: A Short Primer on Employees Versus Independent Contractors \\ History}

The definition of employee is a key component in numerous federal and state statues. The impetus came from the excesses of the industrial revolution which created the intent to provide safety and security to workers and allowing them collective bargaining rights (to form unions), to protect the length of the workday, their wages and benefits, and provide safety and protection from employer discrimination.

In previous eras employees worked for one employer who dictated the work schedule, how the work was performed, wages and benefits, safety, work requirements, hours of work, and the entire workeremployer relationship from "cradle to grave." Many of these regulations stem from these concerns.

\section{Today}

Currently development and use of the internet, cell phones, connectivity, speed of connectivity and access to others around the world have given rise to the "gig" economy where these technologies allow suppliers of products and services and possessors of these product and services to interconnect, conduct business with each other, consummate their business, and exchange value. Thus, someone with a surplus capacity (a plumber who is willing to work afterhours, a person with a car and time) is connected via the internet or mobile devices to someone who wants to use that service.

\section{The Issue}

Do these historical definitions fit the current "gig" economy so that they can be used to draw clear lines between employees and independent contractors, so everyone will know before litigation where that line is. The intent of such rules is to explain the line so that everyone has guidance before action. Do any of the following tests and court cases provide this type of guidance?

\section{Court Cases}

Sisters' Camelot (363 NLBR No. 13 Sept. 25, 2015). Sisters' Camelot is a nonprofit that distributes food to low income and needy individuals. It creates funding by using door to door canvassers who operate on a flexible schedule, choose to work when they want, and can work as much or as little as they desire.

However, upon taking an assignment they are assigned a given area, can only solicit for Sisters Camelot, must keep detailed records and are transported back to the facility.

The N.L.R.B. rued that they were employees under the National Labor Relations Act (29 U.S.C. section 151-169 (2012) by focusing on the terms control and supervisor because the company imposed significant constraints on their choices, opportunities, where they worked, their schedule, and the requirement to keep detailed records. They believed that the canvassers had limited control over their business decisions, profit and losses, where, how, and who to solicit. The board believed in a clear dichotomy that workers are either employees or independent contractors. The issues of control and supervision were critical. Sisters Camelot exercised control over their work even if the canvasses could decide whether to work or not.

\section{The Current Tests}

The Control test governs classification for most of the Federal statues (Stafford, 2016) and focuses on the amount of control by the employer such as the control over how the job is performed, accomplished, the skill required, sources of tools, the location the duration of the relationship, the extent of the employer's discretion of when and how long to work, payment, was the work the regular business of the employee, benefits, tax treatment and others (Stafford, 2016). The IRS has added to these twenty factors which may be an expanded list (Stafford, 2016). 
Economic Realities Test focuses on whether the workers are economically dependent of the employer and is used under the Fair Labor Standards act. They consider six factors:

1. The degree of control that the worker has opposed to the hiring entity.

2. The relative investments by each party in material and equipment.

3. The worker's opportunity for profit or loss considering their managerial skills.

4. The ability, skill, initiative required to do the job.

5. How long the relationship lasts.

6. How integral is the service to the hiring entity's business?

The $A B C$ test begins with the assumption that the worker is an employee. To disprove this the employer has the burden of proving that the workers is truly free from control or direction in the work by the hiring entity, the work is done outside the normal course of the hiring entity's business and is not performed on the hiring entity's facilities, and the worker is usually or customarily engaged in an independent trade, occupation profession or business (Hargrove v. Sleepy's LLC 106 A.3d 449, 458 (N.J. 2015). 


\section{UBER: A GREAT DISRUPTION OR NOT? THE TEACHING NOTE}

\section{OVERVIEW OF THE CASE}

This case examines the story of a successful technology company that grew from a small ride provider in San Francisco into a billion-dollar company. The case has numerous issues for students to study such as regulation, public trust, board issues, founder missteps, a negative corporate culture, negative public reputation, attacks by the industry incumbent, whether it is a disruptive or sustaining innovation and whether Uber drivers are employees or independent contractors? Then students can consider whether it is a disruptor and is it being disrupted by regulators or will its tactics continue to work?

\section{SUGGESTIONS FOR USING THE CASE}

This case has material that would be appropriate for many undergraduate and graduate classes. Entrepreneurship classes could study the rise of a successful venture, the actions of its founder, the founder's missteps and his removal from Uber. Entrepreneurship courses could look at the decision making by the founder and new CEO, the steps the company went through to become successful, and what to do next. Entrepreneur classes could also focus on the skills a founder needs to develop as their business grows from a start up to a billion dollar corporation and when they should step aside. Students can also discuss what emotional intelligence is needed from leaders at the helm of the venture. Human resource management students could examine the culture issues- what would it take to turn a culture around. Students could study the negative organizational culture and the issue of whether the drivers are employees or independent contractors. Law students, employment law, and human resource management classes could struggle with the employee versus independent contractor debate. Strategy Management classes could study Uber's environment, analyze if Uber is a disruptive innovation or not, and make recommendations. This case can be used for marketing courses- how does a company rebuild public trust, image and how can it rebuild its reputation. This case has implications and material for a wide range of courses. The case could also be used in a political science class about the interaction of a dominant company and regulators.

\section{LEARNING OBJECTIVES}

1. Analyze company actions by applying strategic management and marketing principles.

2. Analyze the macro-environmental forces.

3. Analyze the competitive environment using Porter's Five Forces Analysis.

4. Evaluate the leadership, emotional intelligence and actions taken.

5. Make recommendations for future courses of action.

\section{SUGGESTED ASSIGNMENT QUESTIONS}

1. What did Travis do right and wrong? What were some of the issues that the founder, Travis Kalanick, created as the company grew from a nascent venture to a bureaucratic and complex organization. Did Kalanick grow his management skill set from entrepreneur to a leader of a large corporation? Evaluate the actions taken by Travis Kalanick.

2. What marketing and public relations steps should it take. What actions should Uber take to satisfy a worried public- is the emergency/panic button enough?

3. Prepare an analysis of macro-environmental factors and discuss how they impact the industry.

4. Prepare a SWOT analysis

5. Prepare a Porter's Five Forces analysis of the industry.

6. Was Uber a disruptive technology, why or why not?

7. Should traditional companies have seen this change coming and adapt like Uber? 
8. Are Uber drivers employees or independent contractors?

9. What planning should senior management do to place successfully place Uber in whatever the new normal post pandemic is?

10. Can Uber successfully navigate regulation?

\title{
ANSWERS TO QUESTION 1
}

\begin{abstract}
What Did Travis Do Right and Wrong? What Were Some of the Issues That the Founder, Travis Kalanick, Created as the Company Grew From a Nascent Venture to a Bureaucratic and Complex Organization. Did Kalanick Grow His Management Skill Set From Entrepreneur to a Leader of a Large Corporation? Evaluate the Actions Taken by Travis Kalanick.
\end{abstract}

As an entrepreneur, Travis had vision, vigorously pursued his opportunity, obtained pre-seed funding and venture capital, and ran a successful new venture. However, like many entrepreneurs, Travis lacked the skills necessary as the company grew from start-up stages to a high-growth venture. Travis made numerous strategic, tactical, and personal mistakes.

Robert Katz (Organizational Psychologist, 1974 and 2009) argued that 3 skills are necessary for strong management of an organization: technical, interpersonal and conceptual skills. Technical skills provide managers with the ability to achieve goals and objectives. Technical skills can be anything from creating software, to running specialized equipment to analyzing sales, designing products and services, and conducting market analysis. Conceptual skills are skills that allow a manager to see the entire organization as a whole, In other words, they are skills that allow a manager to analyze a problem, analyze the impact to the entire organization and find innovative solutions. Conceptual skills allow managers to predict problems that the business will be confronted with. Interpersonal skills give the managers an ability to work well with others, interact, and communicate effectively with people. These skills are crucial for motivating employees towards better results, meeting the public, press, and public relations.

When analyzing Kalanick, it is evident that his interpersonal skills needed improvement, as well as his conceptual skills. He berated drivers publicly and created a corporate culture that supported sexual harassment. This clearly indicates a lack of mastery of interpersonal and conceptual skills.

Strategically, Uber did not have to alienate Google but could have worked with them on a joint venture of some kind. Similarly, Uber should have been more careful to not alienate Apple. The secret software, Greyball, alienated the public, taxi inspectors, and other regulators and was a public relations disaster. The development of an appropriate organizational culture should start at the top levels- instead the company culture allowed sexual harassment and discrimination. The company was under attack from many stakeholders including investors, the public, drivers, and numerous government entities all over the world.

The tactical and personal mistakes are numerous. He berates an Uber driver and then attempts to placate him with company stock without authorization from the company legal team. When confronted with issues, he claimed the problems were public relations ones not part of his problem. His boasts of sexual conquests and his visit to a karaoke bar with "escorts" was a personal failure not expected of a tech CEO. When confronted, he became combative and defensive. He had to be literally pushed out the door and then according to Newcomer and Stone (2018) attempted a Steve Jobs comeback by recruiting potentially sympathetic board members. In summary, he did not adapt and increase his skill set as the company grew.

\section{ANSWERS TO QUESTION 2}

\section{What Marketing and Public Relations Steps Should It Do? What Actions Should Uber Take to Satisfy a Worried Public- Is the Emergency/Panic Button Enough?}

The company has a public relations issue all over the world. When a PR issue erupts, a CEO should do the following:

- Publicly acknowledge the past issues.

- Clearly indicate actions to address those issues.

- Sometimes use outside panels/groups to provide recommendations. 
- Work with regulators instead of fighting with them.

- Make it clear to the public how they protect drivers' and riders' personal information.

The company should continue to market to millennials, the next generations, and to an increasing number of seniors who want to give up driving but not their freedom to go places.

\section{ANSWERS TO QUESTION 3}

\section{Prepare an Analysis of Macro-Environmental Factors and Discuss How They Impact the Industry.}

The macro, or general, environment is comprised of elements that may impact a company's strategy (Dess, 2019).

\section{Demographics: (Characteristics of the Population)}

Uber depends upon young people to hail rides and they are a major source of the company's income. Millennials comprise a large portion of the population. Generation $\mathrm{Z}$ are reaching adulthood and will likely follow the path of millennials when using apps and smart technology. As seniors age and become less confident in their driving ability and more confident in their use of smart technology, they may be important customers. Seniors - today's baby boomers - comprise a large segment of the population and should be a marketing target (see above).

\section{Sociocultural (Values and Lifestyles of a Society)}

With greater concern for the environment, society may turn away from car ownership and increase use of public transportation, ride sharing, and other means to move around a city. It is unclear what the new normal after the pandemic will be- will employees commute less, work more from home, and use Uber less?

\section{Political/Legal (New Laws/Policies)}

Today, taxis are highly regulated however ride-sharing services are not regulated. This may change in the future. Safety concerns may result in new regulations. Ensuring that drivers are capable may result in more background checks, etc. Determining if drivers are contractors or employees may affect human resource policies. Personal income tax rate cuts have resulted in greater personal income which results in more discretionary income available. Increased corporate profits (as a result of lower taxes) may allow companies to let employees use Uber/Lyft services when travelling.

While Uber was successful in California with Proposition 22 is this a viable strategy in other states. What does it do with the EU's efforts to collect the VAT tax?

\section{Technological (New Innovations)}

Uber has used technological advances to build its company and disrupt the taxi/limousine services. As new technology becomes available, the company will need to respond, make changes, or adapt. The advent of driverless cars, new fuels, new payment systems, will affect the industry. Less corporate travel as a result of webinars, and online meetings from the pandemic may affect business usage of transportation services.

\section{Economic (Characteristics of the National Economy)}

Consumer confidence results in greater consumer spending. However, no one is sure of what the lingering effects the pandemic will have on the economy. The best guess is that some workers and companies will continue to use working at home reducing travel. Uber should use its scheduling skills to forecast and maintain the areas in most demand. 


\section{ANSWERS TO QUESTION 4}

\section{Prepare a SWOT Analysis}

Strengths: good pricing structure/competitive; innovative; good use of technology; use of data analytics to identify customers, usage, etc.; market leadership; international - in global markets; well-known name; brand loyalty; easy for drivers to start working for the company; limited investment since drivers provide their own cars; cash on hand.

Weaknesses: Concerns about profitability; issues with founder; dependent on independent drivers to provide service and maintain company values; dependent on technology to run the business; dependent on customers who are comfortable using apps and smart phones; safety issues --- unqualified drivers, customers not feeling safe, Denver shooting of customer by driver, etc.

Opportunities: increase global usage of smartphones; dissatisfaction with taxis by customers; increased individual income levels; predicted growth in the 'transportation' industry; customers dissatisfied with public transportation

Threats: New entry (low barrier to entry with capital investment); substitute services - alternatives to the company services with public transportation, car ownership, taxis; easy for customers to switch services; potential new regulations; lawsuits. Another threat is continued lawsuits by regulators including city, state, Federal and European entities (Stafford, 2016; Dierken, 2018). Finally, another threat comes from competitors and other technology companies like Apple that complain of Uber tactics (McGarry, 2017). UK and EU regulators will continue to attack Uber.

\section{ANSWERS TO QUESTION 5}

\section{Porters Five Forces Analysis}

This is a tool developed by Michael Porter to analyze the competitive environment of an industry (Dess et al 2019).

\section{Threat of New Entrants}

On a local basis there are few barriers to entry. A driver needs a valid and appropriate driver's license and a car. However, new entrants would have to have access to a mobile application (or develop it), be able to effectively market the service, attract customers, and differentiate itself from current market leaders. To enter on a national or international scale would require a great deal of capital. Threat of new entrant to moderate. There are new entrants in non-US markets.

\section{Power of Buyers}

Customers have little switching costs between services. The industry relies on millions of individual customers and not one major customer for revenue. Buyers have little power.

\section{Power of Suppliers}

Inputs to Uber would include drivers, technology, data analysts, software writers. Although important, there is a supply of each of these crucial inputs, thus they have low power.

\section{Power of Substitute Services}

There are many transportation alternatives available to customers: public transportation, car ownership, walking, biking, etc. Substitutes are readily available, some are lower in price, and can provide similar service (fast service) to Uber. Thus, substitutes pose a high threat. We do not know how many customers 
will come back after the pandemic. One possibility is that ridership will increase if customers are concerned about riding public transit.

There can be an interesting discussion about taxis/limousines to this industry. Are they rivals as suggested by some industry reports or are they substitutes?

\section{Rivalry/Industry Competitors}

There are two major companies in the industry: Uber and Lyft in the United States. Globally, there many new companies entering the industry - some as copycats of Uber and being first to market some entering markets is already established. Some laws and regulations in other countries may make it difficult for Uber to continue to business in the country or to start a business in the country. Low switching costs increases competitive pressures.

Again, it is appropriate to discuss where taxis/limousines fit.

\section{ANSWERS TO QUESTION 6}

\section{Was Uber a Disruptive Technology, Why or Why Not?}

Numerous writers have discussed the theory of disruptive innovation (Markides, 2006; King and Baatartogtokh, 2016; Bower and Christensen, 1995; Cursi and Minin, 2014; Dejon and vanDijk, 2015; Gobble, 2015; Goldstein, 2018; Lepore, 2014; Moazed and Johnson, 2016; Schmidt and Druehl, 2008; Weeks, 2015). Since its debut a number of writers have suggested modifications: Utterback and Acee (2015) with 24 possible models based on different costs, traditional performance, and ancillary performance; Schmidt and Druehl (2008) using two variables the type of innovation and the type of disruption; and Christensen (2015) adding "new market footholds." Some question the value of the theory when many examples fall outside of Christensen's definition (King and Baatartogtokh, (2016).

Scholars and writers are mixed on the issue of whether Uber was disruptive. Two writers in Jain's (2015) article said yes and one said it was a sustaining innovation. Christensen et al (2015) argue that Uber was not a disruptive innovation because the market was well served, started in San Francisco- a higher end market, and did not follow the authors' progression from low end to higher end. These authors specifically cite Uber as not being an example of a disruptive innovation.

A possible but weak argument could be made that it meets Schmidt and Druehl's first category- Uber was a sustaining innovation that started with high end encroachment and then may move downward. However, the innovation did not come from the existing taxi companies but a new entrant that was Uber.

Uber may meet Utterback and Acee's (2005) fourth category of a disruptive innovation which is lower cost, higher traditional performance, and higher ancillary performance. The argument would have to be that Uber's costs are lower, traditional performance is higher because of the convenience, and ancillary performance is higher with rides hailed by a click on a mobile device.

The best critique of disruption theory is by Moazed and Johnson (2016) who argue that Christensen et al are wrong on two points- Uber was a disruptive innovation and the theory should be expanded to include the emergence of platforms as a new business model (Moazed and Johnson, 2016).

Moazed and Johnson's (2016) first argument is that Uber was a disruptive innovation. Christensen's original theory used companies that started with a product or service that they changed or modified. Christensen used the changed or modified product or service as examples of disruptors (Moazed and Johnson, 2016). Uber fits this progression because they started out at the high end black cab and limousine business. They changed their service with the introduction of UberX in San Francisco. It stated at the low end, was less reliable, had longer wait times, and cost more than taxis. As it progressed it improved its network, decreased costs, decreased wait times, and developed rules that vetted drivers. With these improvements it then was able to move upstream and attack the taxi industry. This is a move from the lower to the upper end of a market which Moazed and Johnston (2016) argue is a classic disruption.

The authors' second point is that Christensen's attempt to revise the theory with his "new market footholds" concept missed the point (Moazed and Johnson, 2016). Uber represents a new business model where an entrant builds a platform. The platform grows to provide new products or services to their existing 
customers or expands to new customers. This contrasts with traditional business models which they term "linear" where the organization controls a linear supply chain. Christensen's coauthor argued that a disruptor is a demand driven concept from the customers where the customers' demand drives the supply chain (Moazed and Johnson, 2016). However, this ignores the supply side of this innovation because Uber connects drivers with unused capacity who provide supply.

They argue that the theory needs to be revised to include this new business model of platforms. Using Uber as an example there are two sets of platform customers- riders needing transportation and car owners. The platform connects these two sets of customers. Once the platform is developed then, unlike linear business models, these platform providers can attack from a weaker position, from a competitive position, or enter new markets (Moazed and Johnson, 2016).

Horn (2016) argues that Uber was a disruptive innovation using the following test:

1. "Does it target nonconsumers or people who are overserved by an incumbent's existing offering in the marketplace." His analysis is yes because many people did not use taxis because of the cost but have been using Uber.

2. "Is the offering not as good as an incumbent's existing offering as judged by historical measures of performance." His answer is yes because Uber started serving people who could not afford black cars or limousines but the service was not as reliable as traditional limousine services.

3. "Is the innovation simpler to use, more convenient or more affordable than the incumbent's existing offering." Uber Black was very affordable and convenient.

4. "Does the offering have a technology enabler that can carry its value proposition around simplicity, convenience, affordability upmarket and allow it to improve." Uber's technology platform connects drivers with excess capacity to riders via their phones. This is a technology that can be adapted to other industries.

5. "Is the technology paired with a business model innovation that allows it to be sustainable with its new value proposition." Uber seems to have a sustainable business model that has lower costs than the competition. While currently it operates at a loss, many investors and stockholders see future viability. Others see Uber's many future barriers.

6. "Are existing providers motivated to ignore the new innovation and not threatened at the outset." The authors acknowledge that this is a difficult question. Yes, taxis are fighting Uber via regulators that burden taxis with licenses and other approval processes. No because taxis are not adapting to the new technology - they are not responding to the innovation and being disrupted.

Some students may argue that this debate is meaningless because it is all about definitions and is therefore academic and most importantly misses the point that Uber changed the market. It uses a new technology (phone applications) that the market finds convenient. It disrupted how a rider finds rides and how drivers can earn more income. Taxi drivers were replaced with Uber drivers but employment in this industry increased (Moazed and Johnson, 2016).

In summary, a spirited discussion among the students should be possible.

\section{ANSWERS TO QUESTION 7}

\section{Should Traditional Companies Have Seen This Change Coming and Adapt Like Uber Using DeJong and Van Dijk's (2015) Strategy?}

De Jong and Van Dijk (2015) and others started the discussion of how traditional companies can foresee change and adapt to it. The student's answer is that, like Kodak, the traditional taxicab companies did not see the change and adapt to it. These authors' first step requires traditional companies to outline their industry business model. The traditional companies assumed, like Kodak, that the public would always need them. So, they did not outline or discern their underlying business model. By not taking these first steps they did not reframe their model and change their business. If they had done this soul searching could they have changed their model in time? Students may provide interesting answers, but one can only speculate. 


\section{ANSWERS TO QUESTION 8}

\section{Are Uber Drivers Employees or Independent Contractors?}

Given the recent trends in the "gig" economy students will relate to this question. However, they will struggle as have judges, government entities and others have struggled with this question. The answer depends on which test one uses. Under the control test students could conclude either. All of these companies in order to ensure quality dictate certain rules that must be followed. Uber drivers are monitored by the company and have standards of conduct. They can choose to accept a rider or not. Conversely there is a hint that too many rejections of Uber offers will result in their being terminated.

Sadly, under the economic realities test, students could again conclude either. While many Uber drivers do not rely on the company for the substantial part of their income as their grandparents did for their employers, a few do rely on the income. How many would it take to trigger the line to be labeled as employees. Also, Uber drivers can shut off their app and drive at their own discretion. How does this impact their decision? Freelance employees could be an interesting topic to discuss here, as more and more people are turning to this method of employment.

Also, under the ABC test the students could conclude either. The Uber driver works with their own equipment, off company premises, may have other trades or professions, and chose to use their surplus time and the surplus capacity of their automobile. However, is the work the usual or normal course of the hiring entity's business? Uber argues that it is a technology platform connecting drivers and riders. Conversely it can be argued that this it is in the transportation business. Usually the use of the ABC test places gig workers in the employee category.

So, where are we? There is no consensus among the courts, judges, government entities or the public so there will not be a student consensus either (Hall and Kreger, 2018: Ben-Shahar, 2017: Berg and, Johnson, 2019; Costa, 2016; Recent Adjudication, 2016; Posen, 2015; Stafford, 2016). Enterprising students may argue that the tests are outdated and the gig economy should be left alone - to regulate would kill it. Others may argue that there is now a new class of workers, gig economy workers, who do not fit nicely on either side of the line between employees and independent contractors and new definitions or new legislation may be needed.

\section{ANSWER TO QUESTION 9}

\section{What Planning Should Senior Management Do to Successfully Place Uber in Whatever the New Normal Post Pandemic Is?}

The pandemic will have long term effects on the world's economies. It is unclear how many employees will return to commuting to work. The best guess is that a higher percentage of workers than before will work from home. If this is the case, Uber should plan in flexibility and use its formidable forecasting and scheduling skills to place drivers where the demand is still lucrative.

\section{ANSWER TO QUESTION 10}

\section{Can Uber Successfully Navigate Regulation?}

This is the most difficult question for students because it is a political science policy question. The best guess is that Uber will continue to use the tactics that enabled it to achieve legal status where it operates. They also were successful in California and threaten to use that tactic. The question is would they be willing to spend the amount it took to get Proposition 22 approved in other states or locations? A good question for students is whether or not Uber is a policy disrupter. 


\section{REFERENCES}

Abrosimova, K. (2017). Building an app like Uber: What is the Uber app made from? Retrieved July 8, 2018, from https://yalantis.com/blog/uber-underlying-technologies-and-how-it-actually-works/

Bariso, J. (2017). Uber just fired 20 employees. Here's why, summed up in 1 powerful sentence. Retrieved May 11, 2018, from https://www.inc.com/justin-bariso/uber-just-fired-20-employeesheres-why-summed-up-in-one-powerful-sentence.html

Bariso, J. (2017). Uber's new CEO just sent an amazing email to employees - and taught a major lesson in emotional intelligence. Retrieved May 10, 2018, from https://www.inc.com/justinbariso/ubers-new-ceo-just-sent-an-amazing-email-to-employees-taught-a-major-lesson-inemotional-intelligence.html

Ben-Shahar, O. (2017). Are Uber drivers employees? The answer will shape the sharing economy. Retrieved July 12, 2018, from https://www.forbes.com/sites/omribenshahar/2017/11/15/are-uberdrivers-employees-the-answer-will-shape-the-sharing-economy/\#1bf08a8c5e 55

Berg, J., \& Johnston, H. (2019, January 1). Too Good to be true? A comment on Hall and Krueger's analysis of the labor market for Uber's driver-Partners. IIL Review, 72I(1), 36-68.

Bhuiyan, J. (2016). Uber paid $\$ 680$ million for self driving truck company Otto for the tech, not the trucks. Retrieved July 22, from https://www.recode.net/2016/8/18/12540068/uber-paid-680million-for-self-driving-truck-company-otto-for-the-tech-not-the-trucks

Bhuiyan, J. (2018, May 23). Uber turned a profit thanks to its deals in Southeast Asia and Russia. Retrieved July 2018, from https://www.recode.net/2018/5/23/17380952/uber-2018-financialsyandex-grab-softbank

Blystone, D. (2018). The story of Uber. Retrieved July 10, 2018, from https://www.investopedia.com/articles/personal-finance/111015/story-uber.asp

Bower, J.L., \& Christensen, C.M. (1995, January-February). Disruptive technologies: Catching the wave. Harvard Business Review.

Caro, M.D. (2012, September 25). From the Draconian to the Inane: Uber CEO rips proposed DC regulations.

Christensen, C.M., Raynor, M., \& McDonald, R. (2015, December). The Big Idea: What is Disruptive Innovation? Harvard Business Review, pp. 46-53.

Colombo, S. (2018, February). Behavior and characteristic based price discrimination. Journal of Economics and Management Strategy, 27(2), 237-250.

Corsi, S., \& Di Minin, A.D., (2014). Disruptive innovation...in reverse: Adding a geographical dimension to disruptive innovation theory. Creativity and Innovation Management, 23(1) 76-90. DOI:10.1111/caim.12043

Costa, D. (2016, July). Uber Puerto Rico Launch Hits a Pothole. Caribbean Business, 2(27), 8.

De Jong, M., \& van Dijk, M. (2015). Disrupting beliefs: A new approach to business-model innovation. McKinsey Quarterly $3^{\text {rd }}$ Quarter.

DeMasi, A. (2016, January). Uber: Europe's backseat drive for the sharing economy. Creighton International and Comparative Law Journal, 7, 73-85.

Dess, G.G., McNamara, G., Eisner, A.B., \& Lee, S. (2019). Strategic Management text and cases (9th ed.). McGraw-Hill.

Dierken, B.V. (2018, September 1). UBER's international tax scheme: Innovative tax avoidance or simple tax evasion? Syracuse Journal of International Law and Commerce, 46(1), 223-260.

Dogtiev, A. (2018). Uber revenue and usage statistics 2017. Retrieved July 3, 2020, from http://www.businessofapps.com/data/uber-statistics/

Driebusch, C., \& Roof, K. (2019, April 26). Uber lowers target price for IPO. The Wall Street Journal.

Driebush, C., Farrell, M., \& Chung, J. (2019, May 20). Early big investors in Uber undermined market debut. The Wall Street Journal, 273(117), A1.

Escobari, D., Rupp, N.G., \& Meskey, J. (2019). An analysis of dynamic price discrimination in airlines. Southern Economic Journal, 65(3), 639-662. 
Gobble, M.M. (2015). The case against disruptive innovation Research Technology Management, 58(1), $59-61$.

Goldstein, M. (2018, April 30). Destruction of taxi industry by Uber, Lyft affects Trump lawyer Michael Cohen. Forbes. Retrieved July 2018, from www.forbes.com/sites

Graber, H. (2017). The Uber boycott and Lyft's ACLU donation herald a new era of corporate politics. Retrieved July 20, 2018, from http://www.slate.com/blogs/moneybox/2017/01/30/the uber boycott and lyft s aclu donation herald a new era of corporate.html

Griffin, D.A., Van Esch, P., \& Trittenbach, M. (2018, July). Investigating the mediating effect of Uber's sexual harassment case on the brand: Does it matter? Journal of Retailing and Consumer Services, 43, 111-118.

Hahn, J., Kim, J., Kim, S., \& Lee, J. (2018, May). Price discrimination with loss aversion consumers. Economic Theory, 5(3), 681-728.

Hall, J.V., \& Kreger, A.B. (2018). An analysis of the labor market for Uber's Driver-Partners in the United States. ILR Review, 71(3), 705-732.

Hargrove v. Sleepy's LLC 106 A.3d 449, 458 (N.J. 2015).

Hartmans, A., \& McAlone, N. (2016). The story of how Travis Kalanick built Uber into the most feared and valuable startup in the world. Retrieved June 15, from https://bit.ly/3xNLijM

He, Y., \& Zeng, S. (2019, March). Price discrimination in sharing economy. Western Decision Sciences 2019 Conference Proceedings.

Horn, M. (2016, June 20). Uber: Disruptive innovation and regulated markets. Forbes.

Jain, A. (2015, November 25). Is uber a disruptive innovation? Quora. Retrieved from https://nam04.safelinks.protection.outlook.com/?url=https\%3 A\%2F\%2Fwww.quora.com\%2FIsuber-a-disruptiveinnovation\&amp; data $=02 \% 7 \mathrm{C} 01 \% 7 \mathrm{Cdhoffm} 20 \% 40$ msudenver.edu $\% 7 \mathrm{Ca} 50 \mathrm{~b} 59 \mathrm{e} 32 \mathrm{~d} 7 \mathrm{~b} 47611 \mathrm{c} 7 \mathrm{~d}$ 08d6abf72c98\%7C03309ca417334af9a73cf18cc841325c\%7C1\%7C0\%7C636885475419495737 \&amp;sdata=82252N\%2BeuFMEU1URHWfDXQ3o\%2BSkjBQIL23DA1MBiL50\%3D\&amp;re served $=0$

Jeong, S. (2018). Who blinked first in Waymo v Uber? Why Uber and Waymo settled its high-staked case. Retrieved July 21, 2018, from https://www.theverge.com/2018/2/9/16997394/waymo-v-ubertrial-settlement-explained

Jungleworks. (2017, December). How Uber works: Business revenue model. Retrieved July 2018, from https://jungleworks.com/uber-business-model-revenue-insights

Katz, R.L. (1974 reprinted 2009). Skills of an Effective Administrator. Harvard Publishing Company.

King, A.A., \& Baatartogtokh, B. (2015). How useful is the theory of disruptive innovation? Sloan Management Review, 57(1).

Kolhatkar, S. (2018). At Uber, a new CEO shifts gears. Retrieved July 19, 2018, from https://www.newyorker.com/magazine/2018/04/09/at-uber-a-new-ceo-shifts-gears.

Kosoff, M. (2017). Mass firings at Uber as sexual harassment scandal grows. Retrieved June 1, 2018, from https://www.vanityfair.com/news/2017/06/uber-fires-20-employees-harassment-investigation

Lepore, J. (2014, June). The disruptive machine: what the gospel of innovation gets wrong. The New Yorker. Retrieved from http://www.newyorker.com/magazine/2014/06/23/the-disruption-machine

Luttman, A. (2018, March). Evidence of directional price discrimination in the U.S. airline industry. International Journal of Industrial Organization, 62, 291-329.

Markides, C. (2006). Disruptive Innovation: In need of better theory. Product Innovation Management, $23,1-25$.

McGarry, C. (2017). How Uber ran afoul of Apple's privacy rules. Macworld - Digital Edition, 34(6), 63-64.

McGrath, F. (2017, August 16). The demographics of Uber's US users. Retrieved July 2018, from www.globalwebindesx.com/case-studies 
Moazed, A., \& Johnson, N.L. (2016). Why Clayton Christensen is wrong about Uber and disruptive innovation. Techcrunch.com, 27(2).

Newcomer, E., \& Stone, B. (2018, January 22). The fall of Travis Kalanick was a lot weirder and darker than you thought. Bloomberg Businessweek, (4555).

Posen, H.A. (2015). Ridesharing in the sharing economy: Should regulators impose Uber regulations on Uber? Iowa Law Review, 101, 405-433.

Recent adjudication: Employment Law-National Labor Relations Act-NLRB classifies canvassers as employees, not independent contractors. (2016). Harvard Law Review, 129, 3039.

Saylor, B. (2017, November). Taxi \& Limousine Services in the US. IBIS World Industry Report.

Schechenr, S. (2021, February 20). Uber loses drivers' challenge in U.K. Wall Street Journal, (41).

Schmidt, G.M., \& Druehl, C.T. (2008). When is a disruptive innovation disruptive? Product Development and Innovation Management, 25, 347-360.

Sisters' Camelot (363 NLBR No. 13 Sept. 25, 2015).

Stafford, B.E. (2016, Winter). Comment: Riding the lie between 'employee' and 'independent contractor' in the modern sharing economy. Wake Forest Law Review, 51, 1223.

Stone, B. (2017, January 30). How Uber fought city halls, outlasted rivals and Airbnb won over the citizenry, figured out the sharing economy. Bloomberg Business Week.

Thelen, K (2018, December). Regulating Uber: The politics of the platform economy in Europe and the United States. Perspectives on Politics, 16(4), 938-953.

Uber.com. (2018). website. Retrieved from www.uber.com

Uber.com. (2021). website. Retrieved from www.uber.com

Urbinati, A., Chiaroni, D., Chiesa, V., Franzo, S., \& Frattini, F. (2018). An exploratory analysis on the contextual factors that influence disruptive innovation: The case of Uber. International Journal of Innovation and Technology, 5(3).

Utterback, J.M., \& Acee, H.J. (2005). Disruptive technologies: An expanded view. International Journal of Innovation Management, 9(1), 1-17.

Utterback, J.M., \& Acee, H.J. (2015). Is disruption theory wearing new clothes or just naked? Analyzing recent critiques of disruptive innovation theory. Innovation, 17(4), 417-428. DOI: $10.1080 / 14479338.2015 .1061896$

Weeks, M.R. (2015). Is disruption theory wearing new clothes or just naked? Analyzing recent critiques of disruptive innovation theory, Innovation, 17(4), 417-428. DOI. $10.1080 / 14479338.2015 .1061896$

Wong, J.C. (2017). Uber CEO steps down from Trump advisory council after users boycott. Retrieved July 21, from https://www.theguardian.com/technology/2017/feb/02/travis-kalanick-delete-uberleaves-trump-council 